Federal Reserve Bank of Minneapolis

Research Department

\title{
Clearing Arrangements in the United States before the Federal Reserve System*
}

\author{
Warren Weber \\ Working Paper 695 \\ February 2012 \\ Very preliminary; do not quote or cite. \\ Comments welcome.
}

\begin{abstract}
This paper examines two different clearing arrangements for bank liabilities. One was a profitmaximizing private entity, the Suffolk Banking System. It cleared notes for New England banks between 1827 and 1858. The other was a nonprofit collective, the clearinghouses organized in many cities beginning in 1853. The paper examines how well these arrangements prevented bank failures and acted as lenders of last resort. It finds the Suffolk system had fewer failures but acted less like a lender of last resort. It argues that these differences can be explained by the different incentives facing the Suffolk Bank and the members of clearinghouses.
\end{abstract}

JEL classification: E42, N21

Keywords: Clearinghouses; Moral hazard; Banknotes

*Weber: Federal Reserve Bank of Minneapolis and University of South Carolina. e-mail: weweber@gmail.com. This work was supported in part by the Consortium on Financial Systems and Poverty at the University of Chicago. I thank the Baker Library at the Harvard Business School for the materials provided from its Suffolk Bank Collection. I also thank the participants at the conference "The Optimal Design of Payment System" for helpful comments. The views expressed herein are those of the author and not necessarily those of the Federal Reserve Bank of Minneapolis or the Federal Reserve System. 


\section{Introduction}

Numerous different privately-issued media of exchange (monies) have been used throughout history. Virtually all of these monies have been liabilities that were callable on demand in the sense that they were redeemable on demand in some form of "lawful money." The most common examples were notes issued by private banks. These notes were redeemable on demand in specie. Today, demand deposits are an example of such privately issued media of exchange.

In the cases in which multiple privately issued media of exchange have been in existence, issuers have usually been willing to accept the private monies issued by others in payments of debts or other obligations. ${ }^{1}$ However, issuers rarely would ever redeem the money issued by others. In most instances when one private money issuer would redeem another private issuer's money, the issuers whose demand liabilities were being redeemed were required to make a deposit of lawful money with the redeeming agent.

Under most multiple private media of exchange systems, reissuing the money of another issuer was illegal. The result was that issuers had the incentive to redeem (clear) the monies issued by others that they received as payments in order to increase their reserves of lawful money. In many cases, the desire to clear obligations led to the establishment of organized places where the clearing could take place.

Prior to the establishment of the Federal Reserve System, there were two different types of organized clearing arrangements for the monies issued by banks. These two arrangements were similar in that both were net clearing systems. However, the underlying organizations were quite different. One of these clearing arrangements was run by a private profit-maximizing entity. It was the Suffolk Banking System (SBS) for clearing the notes of New England banks run by the Suffolk Bank located in Boston. The other was a nonprofit collective - the clearinghouse. Clearinghouses were established in many cities in the United States, beginning in 1853 when the first clearinghouse was established in New York.

The purpose of this paper is to examine how well these two different clearing arrangements performed. I will measure performance along two dimensions. The first is the safety and soundness of the banks that were members of the system. I do this by examining the failure rates of banks during a period in which both types of systems were in operation. The second is the extent to which the two arrangements acted as lenders of last resort during banking panics by making available "reserves" to member banks.

The paper finds that there were differences in how these two arrangements performed and argues that these differences were related to the incentives of the banks that either ran or were members of the clearing arrangement. Specifically, the private profit-maximizing arrangement (the SBS) had lower rates of bank failures than the clearinghouses. The paper argues that because the Suffolk Bank could potentially suffer large losses should a member bank fail, it had a great incentive to monitor member banks. Under the clearinghouse arrangement, no bank would suffer a loss rom the failure of another bank simply as a result of being a member of the clearinghouse. With regard to acting as a lender of last resort, the paper finds that the mutual arrangement (the clearinghouses) appeared to provide more reserves in times of financial distress than did the SBS. The paper argues once again that

\footnotetext{
${ }^{1}$ Some evidence to support this conclusion is that "Notes of other banks" is a balance entry that appears on the balance sheets of virtually every bank in the United States prior to 1865. See Weber (2012).
} 
the greater reserves provision was because of the incentive effects of potential losses. If a bank in the SBS that received those additional reserves failed to pay them back, the Suffolk Bank suffered the entire loss. In the clearinghouse arrangement, however, such losses would be shared by all the surviving banks, so the clearinghouse banks as a whole could afford to provide more reserves.

The paper proceeds as follows. The Suffolk Banking System is described in the next section. Clearinghouses are described in Section 3. Section 4 compares the two systems with regard to failure rates and provision of reserves during banking panics. The final section summarizes and concludes.

\section{The Suffolk Banking System}

\section{A. How It Operated}

The Suffolk Banking System was a clearing system for the notes of virtually all banks in New England. It was run by the Suffolk Bank in Boston and was in existence from roughly 1827 until $1858 .^{2}$ It was a net clearing system in which the notes of all member banks were cleared at par. Par clearing was an innovation at the time, because typically the notes of a bank only circulated at par locally. Outside of the local area, the notes of a bank would circulate at a discount. ${ }^{3}$ As a result of the par acceptance of notes for clearing by the SBS, the notes of all banks that were members of the system circulated at par throughout New England.

The SBS worked as follows. Banks that were members of the system were required to make a non-interest-bearing specie deposit at the Suffolk Bank. In exchange, they would receive a credit on the books of the Suffolk Bank, much like the reserves of modern-day banks held at the Federal Reserve are carried on the Federal Reserve's balance sheet. For example, suppose that there were three banks that were members of the SBS, and each was required to deposit $\$ 10,000$ in specie with the Suffolk Bank. Then the balance sheet of the Suffolk Bank would look like the following:

\begin{tabular}{c|c} 
Assets & Liabilities \\
\hline Specie & Due to Bank A \\
$\$ 30,000$ & $\$ 10,000$ \\
& Due to Bank B \\
& $\$ 10,000$ \\
& Due to Bank C \\
& $\$ 10,000$
\end{tabular}

To illustrate how net clearing worked, suppose that on a given day, the following transactions occur:

\footnotetext{
${ }^{2}$ The Suffolk Bank actually started the note clearing business in 1824, but it was not "fairly established" until 1827 (Whitney (1878), 19).

${ }^{3}$ In the terminology of the time, banks outside the local area were referred to as "foreign banks," and many balance sheet entries refer to holdings of "foreign bank notes." See Gorton and Weber (2011) and Weber (2011) for extensive data sets of banknote discounts during the period in which the SBS was in existence.
} 
- Bank A brings in $\$ 5,000$ of Bank C notes.

- Bank B brings in $\$ 22,500$ of Bank A notes.

- Bank C brings in $\$ 2,500$ of Bank A notes and $\$ 2,500$ of Bank B. notes

Then, because notes were net cleared, Bank A's account would be debited by $\$ 20,000$ ( $\$ 5,000$ of C's notes less $\$ 22,500$ brought in by B less $\$ 2,500$ brought in by C). Bank B's account would be credited with $\$ 20,000$ ( $\$ 22,500$ of A's notes less $\$ 2,500$ brought in by C). Bank C's account would remain unchanged ( $\$ 2,500$ of A's notes plus $\$ 2,500$ of B's notes less $\$ 5,000$ brought in by A). The balance sheet of the Suffolk Bank would look like the following:

\begin{tabular}{c|c} 
Assets & Liabilities \\
\hline Specie & Due to Bank A \\
$\$ 30,000$ & $-\$ 10,000$ \\
& Due to Bank B \\
& $\$ 30,000$ \\
& Due to Bank C \\
& $\$ 10,000$
\end{tabular}

However, what is shown above is not what actually would have happened. If Bank A was about to run a negative balance, then the Suffolk Bank had two alternatives. The first alternative was to send Bank A's notes back for redemption, in which case the Suffolk Bank's balance sheet, until it received specie for Bank A's notes, would look like the following:

\begin{tabular}{c|c} 
Assets & Liabilities \\
\hline Specie & Due to Bank A \\
$\$ 30,000$ & $\$ 0$ \\
Bank A notes & Due to Bank B \\
$\$ 10,000$ & $\$ 30,000$ \\
& Due to Bank C \\
& $\$ 10,000$
\end{tabular}

The other alternative was to provide "reserves" to Bank A through an overdraft, in which case the Suffolk Bank's balance sheet would look like the following:

\begin{tabular}{c|c} 
Assets & Liabilities \\
\hline Specie & Due to Bank A \\
$\$ 30,000$ & $\$ 0$ \\
Overdrafts & Due to Bank B \\
$\$ 10,000$ & $\$ 30,000$ \\
& Due to Bank C \\
& $\$ 10,000$
\end{tabular}

This operation on the part of the Suffolk Bank looks very much like the way in which banks borrow today from the discount window at the Federal Reserve. However, there are two differences. The first, based on my examination of some of the directors' records for the Suffolk Bank, is that the Suffolk Bank did not require the overdrafting bank to post collateral. The second is that these "reserves" could be used only to clear balances with other banks in the Suffolk Banking System. They were not subject to withdrawal for "lawful money," as is the case with reserves held on the books of the Federal Reserve. 


\section{B. The Advantages of Belonging}

There were two actual advantages and one supposed advantage to a New England bank from belonging to the Suffolk Banking System. The first actual advantage was that it permitted a wider circulation of a bank's notes becasue they circulated at par throughout New England. ${ }^{4}$

The second advantage to belonging to the SBS is that banks received insurance against the failure of other banks. Once the notes of a bank were accepted for clearing and the account of the bank submitting them was credited, the liability was the Suffolk Bank's. Thus, banks were saved the cost of monitoring other banks, which they would have done if they had had to bear the liability. Of course, the insurance was not complete because the Suffolk Bank could fail.

The supposed advantage to a bank of belonging to the Suffolk Banking System is that banks saved on the amount of specie reserves that they had to hold to redeem their notes on demand. Suppose that the banks in New England had not been part of a Suffolk-like system. Then note clearing among them would have been a gross clearing system. That is, they would have had enough specie on hand to redeem their own notes as they were presented either by individuals or by other banks. The SBS, in contrast, was a net clearing system, so that a bank could use the notes of another bank to redeem its notes when presented by that bank. That meant the banks could hold fewer specie reserves against their notes, which meant that they could make more interest-earning loans.

I say that this is a supposed advantage because it does not appear that New England banks held a lower specie ratio than did similar banks outside New England. To show this, I plotted the ratio of specie to notes plus deposits for banks in Massachusetts located outside Boston and for banks in New York outside of New York City. I include deposits in the computation because banks would also have had to hold specie to redeem deposits. The result is shown in Figure 1.

\section{The Suffolk Bank's Incentives}

Regardless of which of the two alternatives that the Suffolk Bank might choose if a bank in the System ran negative balances with it, the Suffolk Bank could suffer losses if that bank were to fail. In the case of the first alternative, it was holding the notes of Bank A, and if Bank A were to fail before Suffolk could get them redeemed in specie, then Suffolk would suffer a loss. In the case of the second alternative, Suffolk would bear a loss if Bank A were to fail before paying off the overdraft.

Because of the possibility of bearing losses, the Suffolk Bank would have an incentive to monitor and "regulate" the banks that were part of the System. Of course, how strong the incentive was depended on how big the potential losses could be.

To get some idea of how much the Suffolk Bank's capital would be exposed if banks in the SBS were to fail, I treat the SBS as if it were a stand-alone entity along the lines shown in the previous balance sheets. I first compute the negative net worth of this entity, which I will call Net due to banks:

\footnotetext{
${ }^{4}$ The evidence to support this conclusion is that the discounts in both New York and Philadelphia on the notes of banks in all the New England states were identical every month except for banks that were closing or near the Canadian border and therefore did not join the SBS. This was not true of the discounts on the notes of banks in other groups of states. See Gorton and Weber (2011) and Weber (2011).
} 


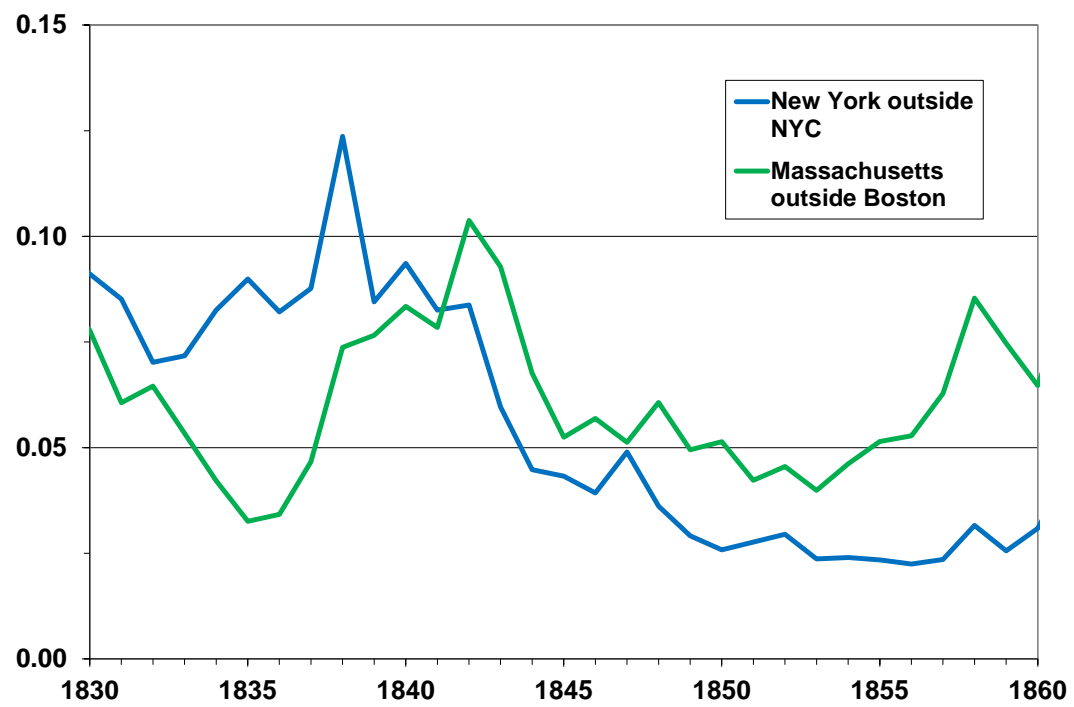

Figure 1: Ratio of Specie to Notes + Deposits for Massachusetts and New York Banks

Net due to banks $=$ due to banks $-($ specie + due from banks + notes of other banks $)$.

That is, I compute the amount that the SBS owed to other banks less the resources that it had on hand, which I consider to be its specie, the amount of other banks' notes that it had on hand, and the amount owed it by other banks.

This computation of Net due to banks is displayed in Figure 2 as the solid red line along with the capital of the Suffolk Bank itself. The figure shows that the net amount due to other banks is mostly positive, indicating that the Suffolk Bank was a net debtor to the banks that were part of the Suffolk Banking System, averaging about 17 percent of capital until about 1854 when it became a net creditor.

To see the incentive effects that the Suffolk Bank would have to monitor and regulate the other banks in the System, I assumed the SBS was a stand-alone entity and calculated this entity's negative net worth under the assumption that the Suffolk Bank would be able to realize only 50 percent of the par value of the notes of other banks and the overdrafts (due from other banks) on its books. My reason for reducing these amounts is that if other banks failed, then the SBS might not have been able to receive specie for all of the notes of other banks when it tried to redeem them, and other banks might not have been able to fully pay off their overdrafts.

This computation, which I call Net due to other banks* is displayed as the dashed green line in Figure 2. Note that the net debtor position of the Suffolk Bank is much larger, now averaging 86 percent of capital if only the period up to 1854 is considered. Note also 


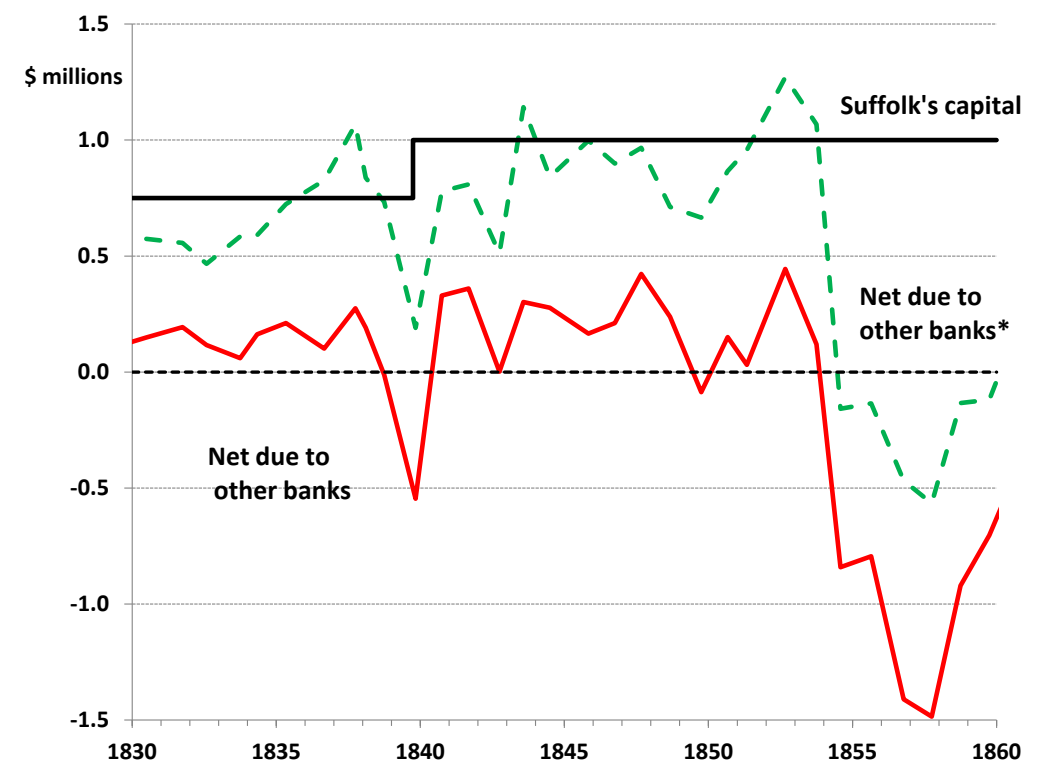

Figure 2: Suffolk Bank's net due to other banks and capital, 1830 - 1860

that there are times when the dashed line is above the Suffolk Bank's capital. This means that if it were the case that the Suffolk Bank had to pay off the banks that had positive account balances with it, but it was able to take the notes of banks that were in its Foreign Money Department and only collect 50 percent of their par value, and if it were able to get only 50 cents on each dollar of overdrafts that it loaned, then either its shareholders would be completely wiped out or it would have to liquidate some of the other assets held by the bank.

The Suffolk Bank did monitor and regulate the behavior of banks that were members of the SBS. For example, the following is an except from a letter from the president of the Suffolk Bank to the president of bank in Vermont:

It appears evident ... that too large a portion of your loan is in accommodation paper, which cannot be relied upon at maturity to meet your liabilities.... [W] hope you will take measures to change the character of your loan, and render it more available in case of need.

\section{Clearinghouses}

The first clearinghouse in the United States was established in New York City in 1854. It had 52 banks as members. Clearinghouses were later established in other cities, and by the 1900s, 115 cities had a clearinghouse. The membership was some, but not necessarily all, of the banks and trusts in a city. Clearinghouses were owned by the member banks.

Like the SBS, clearinghouses used net clearing rather than gross clearing to clear the deposits (and notes) of the member banks. Unlike the SBS, however, banks did not have to post collateral or deposit "lawful money." In other words, there was no system of "reserve 
accounts" as in the SBS or like banks have today at the district banks of the Federal Reserve System.

The net clearing process at clearinghouses took place as follows. Early in the morning, banks brought in the checks of other member banks that they wanted to have cleared. The Manager of the clearinghouse (and his clerks) then determined the net debt or credit position of each bank. After that, debtor banks paid the amount due to the Manager, after which he paid the creditor banks. The payments by debtor banks and payments to creditor banks occurred at set times.

If a debtor bank was unable to pay the balance at the appointed time, all accounts were adjusted to take this into account. In other words, a complete "unwinding" of all transactions involving that bank took place. This provides another contrast with the SBS. Because all transactions would be unwound, the losses from the failure of any clearinghouse member bank was borne by the individual banks. The clearinghouse did not bear any losses, which meant that, unlike the Suffolk Bank, no insurance against losses was provided to member banks by the clearinghouse.

Settlement by debtor banks could occur in several ways:

- with "lawful money"

- with manager's checks, which stated that Bank A was owed $x$ dollars by Bank B. They were called manager's checks because signed by manager of clearinghouse

- by borrowing or lending with other banks

- by drafts on other cities

- with clearinghouse certificates (more on these later).

The clearinghouse did some monitoring of the behavior of member banks. Member banks had to furnish a weekly statement of condition. Further, any member could be expelled for "cause deemed sufficient" by a majority vote.

\section{A Comparison of the Two Systems}

I now present a comparison of how well the two different systems of interbank clearing operated. I use two criteria. The first is how successful they were at controlling the number of bank failures. The second is whether their behavior might have lessened the impact of banking panics on economic welfare.

\section{A. Safety and Soundness}

To compare how well the two systems did at controlling bank failures, I examine the period January 1853 through December 1857, which is the time when the SBS and the New York Clearinghouse were both in operation. The failure rate of banks in the two systems is given in Table 1.

The table shows that overall, the failure rate for banks in the Suffolk Banking System was about half of that for banks in the New York Clearinghouse. Further, the failure rates are lower for banks in each New England state, with the exception of Maine. This exception may be because some Maine banks may not have joined the SBS due to their location close to the Canadian border. I have not been able to determine whether or not this is the case. 


\begin{tabular}{lccc} 
Location & $\begin{array}{c}\text { Number } \\
\text { of banks }\end{array}$ & $\begin{array}{c}\text { Number of } \\
\text { failures }\end{array}$ & $\begin{array}{c}\text { Failure } \\
\text { percentage }\end{array}$ \\
\hline New York & 52 & 6 & 11.5 \\
Suffolk (overall) & 224 & 14 & 5.7 \\
$\quad$ Boston & 32 & 2 & 6.3 \\
Massachusetts, outside Boston & 105 & 1 & 1.0 \\
Maine & 44 & 7 & 15.9 \\
New Hampshire & 31 & 1 & 3.2 \\
Vermont & 32 & 3 & 9.4 \\
\hline
\end{tabular}

Table 1: Failure Rates of Banks in the Suffolk Banking System and in the New York Clearinghouse, January 1853 - December 1857

\section{B. Bank Panics}

A bank panic is a situation in which the vast majority of depositors and noteholders want to redeem their deposits and notes for specie. Because banks are holding fractional reserves, it is impossible for banks to immediately meet these demands. That is, banks are illiquid, even though they may be solvent, at least if assets are valued at the prices prevailing when the panic begins. Banking panics are a problem because they disrupt economic activity and payments systems.

In response to a panic, banks would like to take one or all of the following actions:

1. Get more specie. However, this is impossible in the aggregate. Under the commodity money system like that in the United States during this period, the stock of specie is fixed in the short run. The stock of specie is increased only through inflows of gold and silver from other countries. Because there was no central bank that could change the discount rate and influence gold flows through this mechanism (as did the Bank of England on occasion, for example), the only way in which aggregate specie could increase in the United States was through foreign trade surpluses.

2. Reduce outstanding note and deposit liabilities. The way in which banks could do this was by calling in loans, because loans would be paid off by creditors giving the bank deposits or banknotes. However, although calling in loans reduces a bank's demandable liabilities, it does not increase the amount of specie a bank has on had to meet demands for redemption of notes or deposits.

3. Conserve specie. In other words, it could suspend specie payments. However, banks were legally prohibited from suspending specie payments on their notes. If a bank did suspend, banking authorities had the power to close the bank. ${ }^{5}$

\footnotetext{
${ }^{5}$ Nonetheless, there were times when specie payments were suspended. These suspensions occurred when for some reason a large number of banks in a city or state faced the possibility of running out of specie and therefore the possibility of being unable to redeem their notes on demand. In such cases, banking authorities would usually permit widespread (citywide or statewide) suspensions of payments to occur with no threat of closing the banks.
} 


\section{Suffolk Bank Behavior during Panics}

One major, nationwide panic occurred during the time that the SBS was in operation. It began with a nationwide suspension of specie payments on banknotes beginning in early May 1838. In New England and New York, the panic ended in May 1838 when banks in those areas resumed payments. ${ }^{6}$

The behavior of the Suffolk Bank, which also suspended specie redemption of banknotes during the panic, was motivated by two conflicting objectives with regard to the SBS. On the one hand, it would have liked to reduce the amount of loans that it made to other banks. This would reduce the potential losses that it could suffer, should the banks to which it had made loans subsequently fail.

On the other hand, the SBS was an extremely profitable operation for the Suffolk Bank. ${ }^{7}$ Therefore, the Suffolk Bank had an incentive to keep the SBS in operation, which meant potentially acting as a lender of last resort to some banks.

In actuality, the Suffolk Bank did continue to lend to other banks. For example, Whitney (1878) documents that the Merchant's Bank in Providence, Rhode Island, received a $\$ 350,000$ overdraft from the Suffolk Bank. ${ }^{8}$

Other evidence is provided by the behavior of the total amounts due to Suffolk from other banks during this period, which is displayed in Figure 3. The amount due to other banks was about $\$ 500,000$ through May 1835 . Then, even before the panic, it rose to about $\$ 1$ million in September 1836. It stayed at that level until November 1839, which was after New England banks had resumed specie payments on their notes. After that time, it returned to the pre-panic level of about $\$ 500,000$.

Some other evidence indicates that the Suffolk Bank's behavior in providing overdrafts to other banks may have lessened the severity of the economic downturn in New England. The first piece of evidence is that banks in New England did not suspend for a second time in October 1839, when. with the exception of banks in New York and part of New Jersey, banks in the rest of the country suspended for a second time. A second piece of evidence, shown in Figure 4, is that bank loans declined more gradually in Massachusetts than in Pennsylvania after the 1837 panic began. The third piece of evidence, shown in Figure 5, is that prices of railroad stocks declined much less in New England than they did in the mid-Atlantic states during the period of the panic.

\section{Clearinghouse Behavior during Panics}

Clearinghouses also acted to facilitate interbank clearing during financial panics. They did so by issuing clearinghouse loan certificates. These were large denomination financial instruments that could only be used to settle balances within the clearinghouse. A typical clearinghouse certificate contained wording such as, "This certificate will be received in payment of balances at the Clearing House for the sum of XXX Dollars, from any Member of the Clearing House."

\footnotetext{
${ }^{6}$ Banks in other parts of the country did not resume until the fall of 1838 , and then they suspended again in October 1839. In parts of the country, this second suspension lasted until 1842.

${ }^{7}$ see Rolnick, Smith, and Weber (2003).

${ }^{8}$ Although Rhode Island banks technically were not part of the SBS, many of them cleared notes of New England banks with the Merchant's Bank, which in turn cleared these notes through the SBS. Therefore, the continued operation of the Merchant's Bank was of great importance to the Suffolk Bank.
} 


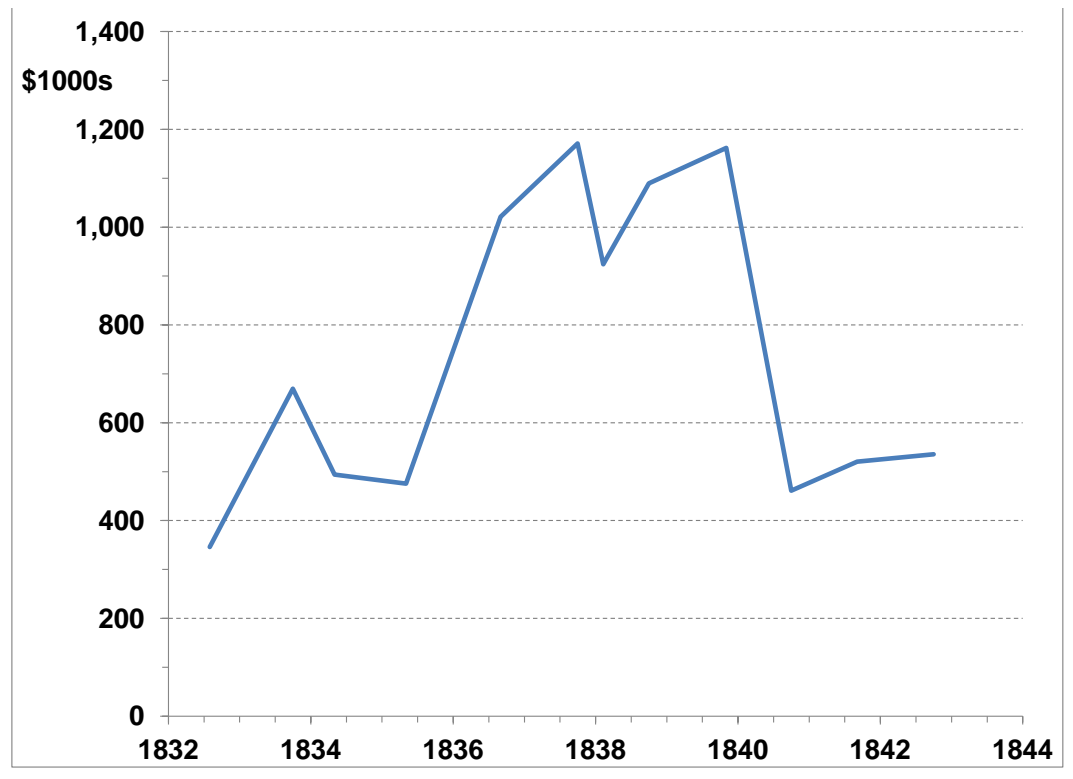

Figure 3: Due from other banks to Suffolk Bank, 1832-1842

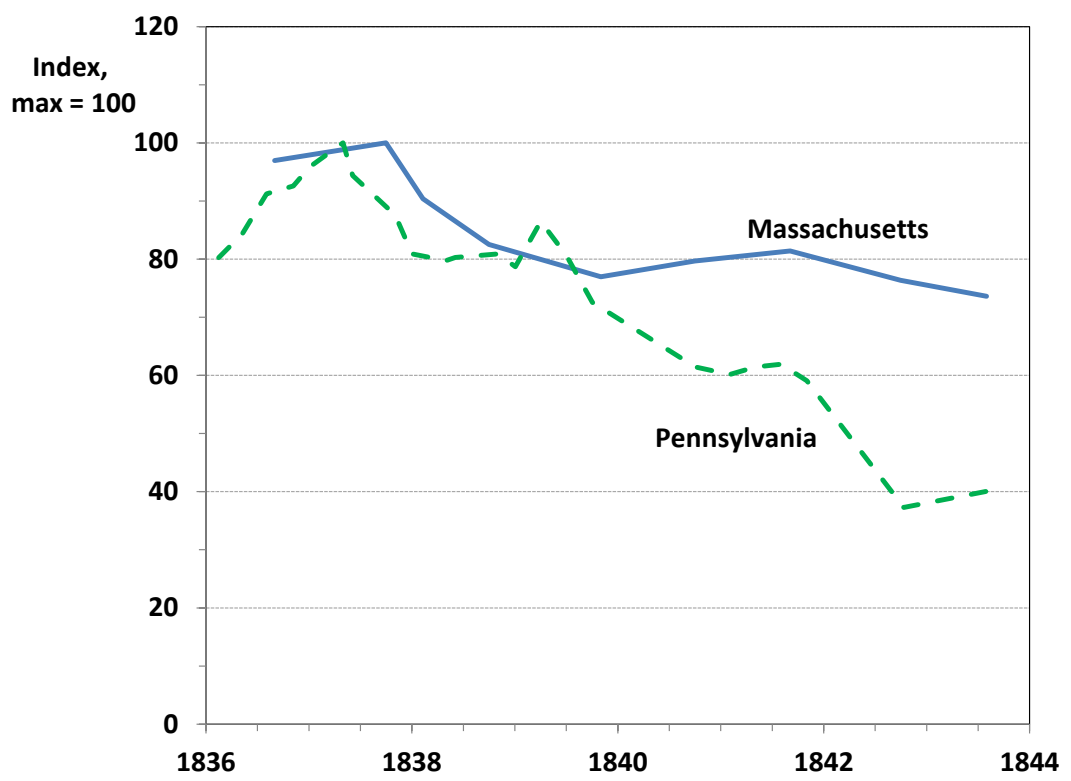

Figure 4: Bank loans in Massachusetts and Pennsylvania, 1836-1843 


\section{Geographical Indices of Railroad-Stock Prices Quarterly, 1834-45}

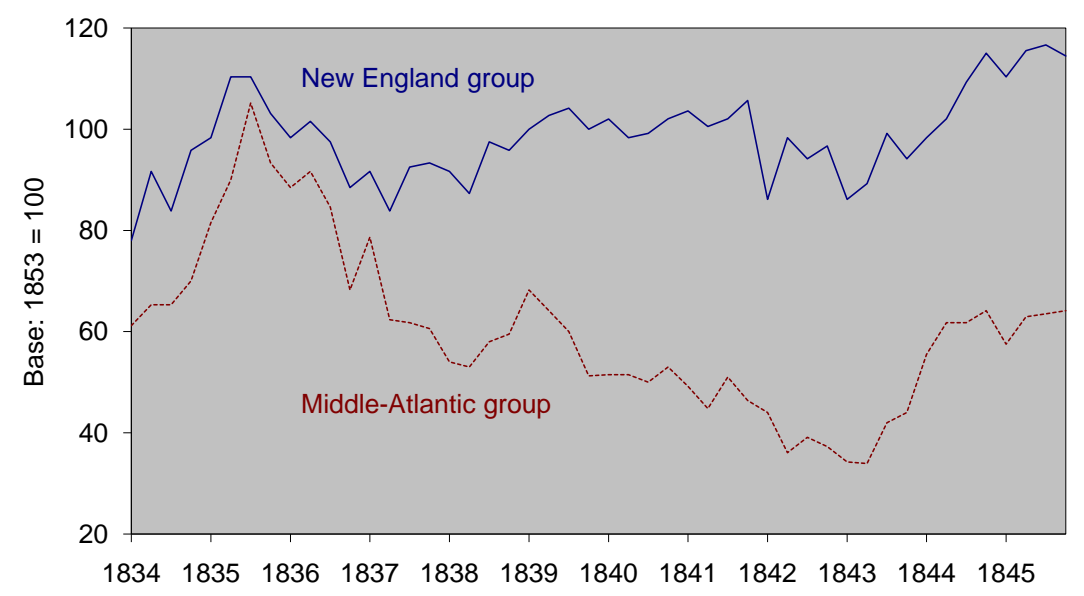

Figure 5: Geographical Indices of Railroad Stock Prices, Quarterly, 1834-1845

The certificates were issued upon the borrowing bank depositing collateral with the clearinghouse. This collateral could be in the form of bills receivable, stocks, bonds, or other securities. The effect was that these financial instruments could now be used to settle balances among banks, whereas in normal times the only means of settlement were those discussed in Section 3 above. The discounts ("haircuts," to use modern terminology) on the collateral were the same for all banks in a clearinghouse, and the interest rate charged to borrowing banks was also the same for all banks. The interest rates charged were high, usually between 6 percent and 7 percent.

Major issuances of clearinghouse loan certificates occurred during four financial panics between 1873 and 1907. In 1873, seven clearinghouses issued loan certificates in the amount of $\$ 41.5$ million. In 1890, three clearinghouses issued them. In 1893, at least nine clearinghouses issued loan certificates in the amount of $\$ 66.3$ million. The largest issuance of clearinghouse loan certificates occurred in the Panic of 1907. During that panic, clearinghouse loan certificates were issued by at least 42 clearinghouses in the amount of approximately $\$ 237.2$ million.

The Panic of 1907 also saw an innovation in the form of the certificates. The innovation is that clearinghouse certificates were now issued in small denominations and were intended for circulation among the general public, whereas in the previous three instances they were issued in large denominations and were not intended for circulation by the general public. These small denomination loan certificates went by several different names: 
- Clearinghouse loan certificates payable only through clearinghouse

26 clearinghouses ( $\$ 41.5$ million)

- Clearinghouse checks payable only through clearinghouse

4 clearinghouses ( $\$ 12.0$ million)

- Cashier's checks payable only through clearinghouse

22 clearinghouses ( $\$ 11.5$ million)

- Paychecks payable to bearer only through clearinghouse

4 clearinghouses (\$47.0 million)

Some evidence indicates that these small denomination certificates were accepted as media of exchange, at least in the local area. I have not been able to obtain evidence about whether or not they circulated at a discount to specie.

An interesting aside with regard to these certificates is that even though they were issued in "small denominations," in some cases these denominations were "too large," which exacerbated the specie shortage problem. If small purchases were made with certificates that had too large a denomination, "tradespeople were obliged to make change with cash, which soon exhausted their supply,"(Cannon (1910), 125).

\section{Summary and Conclusion}

In this paper I considered two different organized clearing arrangements for bank liabilities. One was a profit-maximizing private entity. This was the Suffolk Banking System run by the Suffolk Bank in Boston. It cleared notes for virtually all banks in New England between 1827 and 1858. The other was a non-profit collective. These were the clearinghouses that were organized in many cities beginning in 1853.

I examined how well these two different clearing arrangements performed along two dimensions. The first was the safety and soundness of the banks that were members of the system as measured by the failure rates of banks during a period in which both types of systems were in operation. The second was the extent to which the two arrangements acted as lenders of last resort during banking panics by making available "reserves" to member banks.

I found that there were differences in how these two arrangements performed and that these differences were related to the incentives of the banks that either ran or were members of the clearing arrangement. Specifically, the private profit-maximizing arrangement (the SBS) had lower rates of bank failures than the clearinghouses. The paper argues that because the Suffolk Bank could potentially suffer large losses should a member bank fail, it had a great incentive to monitor member banks. Under the clearinghouse arrangement, no bank would suffer a loss from the failure of another bank simply as a result of being a member of the clearinghouse. With regard to acting as a lender of last resort, the paper finds that the mutual arrangement (the clearinghouses) appeared to provide more reserves in times of financial distress than did the SBS. The paper argues once again the greater reserve provision was because of the incentive effects of potential losses. If a bank in the SBS that received those additional reserves failed to pay them back, the Suffolk Bank suffered the entire loss. In the clearinghouse arrangement, however, such losses would be shared by all the surviving banks, so the clearinghouse banks as a whole could afford to provide more reserves. 


\section{References}

Cannon, J. G. (1910): Clearing Houses. National Monetary Commission, Washington, Government Printing Office.

Gorton, G., and W. E. Weber (2011): "Quoted Discounts on State Bank Notes in Philadelphia, 1832-1858," Research Department, Federal Reserve Bank of Minneapolis, http://www.minneapolisfed.org/research/ economists/wewproj.cfm.

Rolnick, A. J., B. D. Smith, and W. E. Weber (2003): "Establishing a Monetary Union in the United States," in Evolution and Procedures in Central Banking, ed. by D. E. Altig, and B. D. Smith, pp. 227-255. Cambridge University Press, New York.

Weber, W. E. (2011): "Quoted Discounts on State Bank Notes in New York, Cincinnati, and Cleveland, selected dates, 1827-1858," Research Department, Federal Reserve Bank of Minneapolis, http://www.minneapolisfed.org/research/ economists/wewproj.cfm.

(2012): "Balance sheets for U.S. Antebellum State Banks," Research Department, Federal Reserve Bank of Minneapolis, http://www.minneapolisfed.org/research/ economists/wewproj.cfm.

Whitney, D. R. (1878): The Suffolk Bank. Riverside Press, Cambridge, MA. 